University of Nebraska - Lincoln

DigitalCommons@University of Nebraska - Lincoln

Case Study of Multiyear Precipitation Variations and the Hydrology of Fort Cobb Reservoir

Jurgen D. Garbrecht

USDA

Jeanne M. Schneider

USDA

Follow this and additional works at: https://digitalcommons.unl.edu/usdaarsfacpub

Part of the Agricultural Science Commons

Garbrecht, Jurgen D. and Schneider, Jeanne M., "Case Study of Multiyear Precipitation Variations and the Hydrology of Fort Cobb Reservoir" (2008). Publications from USDA-ARS / UNL Faculty. 464.

https://digitalcommons.unl.edu/usdaarsfacpub/464

This Article is brought to you for free and open access by the U.S. Department of Agriculture: Agricultural Research Service, Lincoln, Nebraska at DigitalCommons@University of Nebraska - Lincoln. It has been accepted for inclusion in Publications from USDA-ARS / UNL Faculty by an authorized administrator of DigitalCommons@University of Nebraska - Lincoln. 


\title{
Case Study of Multiyear Precipitation Variations and the Hydrology of Fort Cobb Reservoir
}

\author{
Jurgen D. Garbrecht ${ }^{1}$ and Jeanne M. Schneider ${ }^{2}$
}

\begin{abstract}
Impacts of decadal precipitation variations on reservoir inflow, flood releases, and pool elevation were investigated for the Fort Cobb Reservoir, which controls runoff from a $787 \mathrm{~km}^{2}$ agricultural watershed in central Oklahoma. The difference in mean annual precipitation between multiyear dry and wet periods was 33\% of the long-term mean and led to a corresponding $100 \%$ change in mean reservoir inflow, $170 \%$ change in mean annual flood releases from the reservoir, and a maximum drop in conservation pool elevation of $2 \mathrm{~m}$. From a reservoir operations perspective, only the frequency of controlled flood releases was impacted by decadal precipitation variations. These flood releases were sporadic in nature, and the more frequent releases during wet periods were not believed to appreciably enhance stream habitat and riparian vegetation downstream of the reservoir. It was further reasoned that large differences in annual reservoir inflow due to decadal precipitation variations would likely be accompanied by related changes in upstream soil erosion and reservoir sediment loading. With regard to hydrologic and environmental modeling, it was argued that decadal precipitation variations had important implications for model calibration, verification, and subsequent application. Overall, this case study demonstrated watershed and reservoir hydrology were sensitive to decadal precipitation variations and suggested that decadal precipitation variations deserved careful consideration in hydrologic and water quality investigations in central Oklahoma.
\end{abstract}

DOI: 10.1061/(ASCE)1084-0699(2008)13:2(64)

CE Database subject headings: Climatology; Precipitation; Hydrology; Watersheds; Reservoir operation; Case reports; Oklahoma.

\section{Introduction}

Persistent, multiyear increases or decreases in mean annual precipitation and resulting runoff can affect downstream reservoir operations, as well as related recreational activities, water quality, and stream and shoreline ecosystems. Previous studies established the existence of multiyear precipitation variations lasting 5 or more years, called decadal variations [e.g., Gray et al. (2004); Garbrecht and Rossel (2002); Hu et al. (1998); NRC (1998); Dettinger et al. (1998)]. A follow-up study demonstrated the strong impact of climate on average annual stream flow for 10 agricultural watersheds ranging in size from 800 to $11,500 \mathrm{~km}^{2}$ (Garbrecht et al. 2004).

This case study focuses on the impact of decade-long precipitation variations on the hydrology of the Fort Cobb Reservoir, a reservoir that controls runoff from a $787 \mathrm{~km}^{2}$ agricultural watershed in central Oklahoma. In 1998, the Fort Cobb Reservoir was identified as a water body that did not meet the water quality standards set forth in the Clean Water Act of 1987, and it has been the object of nonpoint source pollution investigations (Storm

${ }^{1}$ Research Engineer, USDA, ARS Grazinglands Research Laboratory, 7207 West Cheyenne St., El Reno, OK 73036. E-mail: jurgen.garbrecht@ ars.usda.gov

${ }^{2}$ Research Meteorologist, USDA, ARS Grazinglands Research Laboratory, 7207 West Cheyenne St., El Reno, OK 73036. E-mail: jeanne.schneider@ars.usda.gov

Note. Discussion open until July 1, 2008. Separate discussions must be submitted for individual papers. To extend the closing date by one month, a written request must be filed with the ASCE Managing Editor. The manuscript for this paper was submitted for review and possible publication on May 17, 2006; approved on April 5, 2007. This paper is part of the Journal of Hydrologic Engineering, Vol. 13, No. 2, February 1, 2008. @ASCE, ISSN 1084-0699/2008/2-64-70/\$25.00. et al. 2006; Yue and Derichsweiler 2005). Currently, the Fort Cobb Reservoir watershed is part of the Conservation Effects Assessment Project (CEAP), a multiagency effort to quantify the environmental benefits of conservation practices (Mausbach and Dedrick 2004).

A particular aspect that has received little attention, but which may have far-reaching implications for water quality investigations, is the change in reservoir inflows due to persistent variations in average annual precipitation lasting 5 to 30 years, which are referred to as decadal precipitation variations. Impacts of such long-term variations have the potential to surpass impacts of short-term variations due to their cumulative effects (Mantua et al. 1997; Woodhouse and Overpeck 1998). Examples of climate variations in the United States include the Dust Bowl years of the 1930s (Worster 1982); the record low- and high-water levels of the Great Lakes in the 1960s and 1970s (Croley 1995); the 1980 rise in the Great Salt Lake (Lall and Mann 1995); and most recently, the persistent multiyear drought in the Colorado River Basin (Webb et al. 2004).

Objectives of this study were to quantify the effects of decadelong precipitation variations during the 1940-2004 period on reservoir inflow, flood releases, and pool elevation for the Fort Cobb Reservoir. Extreme and reservoir-design storm events have return periods well beyond the durations of decadal variations and are outside the scope of this investigation. The purpose of this study was to bring attention to potential impacts of decade-long precipitation variations and help establish whether they ought to be considered in water quality, reservoir operation, and stream ecosystem investigations. The findings and implications of this study should be of particular interest for investigators and water resources managers dealing with watershed and reservoir hydrology and associated downstream impacts in the presence of decadelong precipitation variations. 


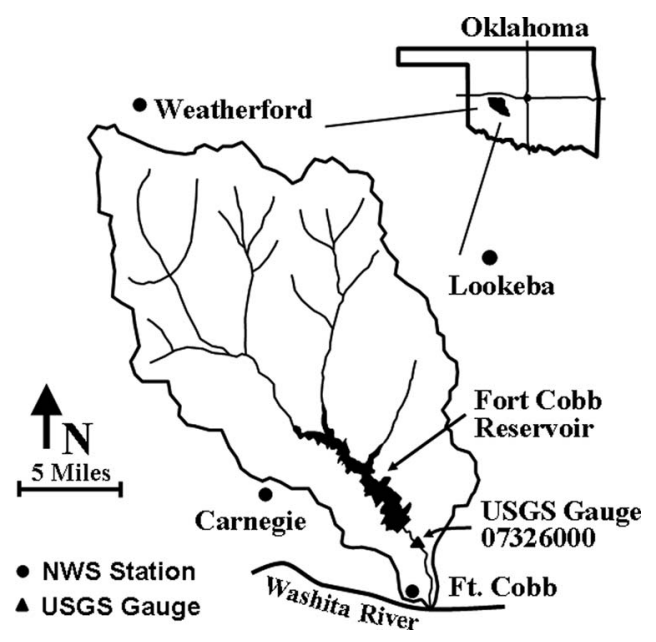

Fig. 1. Fort Cobb Reservoir watershed and locations of National Weather Service cooperative weather stations and U.S. Geological Survey stream gauge 07326000

\section{Data Source and Preparation}

Four National Weather Service (NWS) cooperative weather stations (Weatherford, Lookeba, Carnegie, and Fort Cobb) with long-term daily precipitation data were available in the vicinity of the Fort Cobb Reservoir watershed (Fig. 1) (OCS 2005). Daily precipitation records were about $97 \%$ complete. Missing values were filled with data from other nearby NWS weather stations and three Oklahoma Mesonet stations (Crawford et al. 1992; Elliott et al. 1994). Monthly and annual precipitation for the watershed were calculated from daily precipitation at the four NWS stations

Stream flow from January 1940 through March 1959 was available for a U.S. Geological Survey (USGS) stream gauge near the mouth of Cobb Creek watershed (USGS station 0732600, drainage area $826 \mathrm{~km}^{2}$ ) (USGS 2005). In April 1959, Fort Cobb Dam and Reservoir, a multipurpose project for municipal and industrial water supply, flood control, recreation, and fish and wildlife, was completed by the Bureau of Reclamation (BOR) $5 \mathrm{~km}$ upstream of the USGS gauging station. From April 1959 through December 2004, monthly reservoir inflows were calculated by the BOR from the sum of water supply deliveries, flood releases, evaporation, seepage, and change in storage. Water withdrawals for the cities of Chickasha and Anadarko and the Western Farmers Electric Cooperative were measured by the Fort Cobb Reservoir Master Conservancy District (FCRMCD) at the intake of the Anadarko and Chickasha aqueducts; flood releases were determined from outlet works releases directed by the U.S. Army Corps of Engineers (USACE), Tulsa District; monthly reservoir evaporation was determined from pan evaporation measurements by the FCRMCD; seepage was estimated by the BOR to equal $1 \mathrm{~mm}$ (0.03 in.) per month; and change in storage was determined by reservoir elevation changes recorded by the FCRMCD and USACE equipment at the dam. Pan evaporation was available starting in 1970.

For years prior to 1970, the writers estimated pan evaporation from a linear regression of existing monthly mean air temperature and pan evaporation $\left(R^{2}=0.82\right)$. Water losses for initial soil saturation during reservoir filling and for saturated infiltration were estimated by the writers. Initial saturation of the soil profile was assumed to require $0.3 \mathrm{~m}$ of water; with a $30 \%$ soil porosity, this would saturate the first $0.9 \mathrm{~m}$ of the soil profile. Initial infiltration was assumed to be $244 \mathrm{~mm}$ per month over the flooded area during the first year of reservoir filling in 1959 and was assumed to gradually decline to $152 \mathrm{~mm}$ per month by March 1962, the date at which the conservation pool was first filled. Thereafter, infiltration was assumed to decline further due to self-sealing of the reservoir bottom to $9 \mathrm{~mm}$ per month by the end of 1969 , a value reported as seepage loss by the BOR since 1987.

Location and drainage area $\left(826 \mathrm{~km}^{2}\right)$ of the USGS stream gauge below Fort Cobb Dam do not coincide with the location and drainage area $\left(777 \mathrm{~km}^{2}\right)$ of the BOR reservoir inflows. For combined use, the USGS stream flow record must be adjusted to reflect the same drainage area as that of the reservoir inflow. USGS stream flow was reduced by $6 \%$ to represent runoff from the area draining into the Fort Cobb reservoir. Reducing USGS stream flow proportional to the reduction in drainage area is justified because spatial variability in climate, land use, and topography were not appreciable over the watershed. After this adjustment, both BOR and adjusted USGS flow records were combined into a 1940-2004 monthly reservoir inflow record. Furthermore, stream flow and reservoir inflow were expressed as runoff depth per unit area to facilitate water budget calculations and comparison of runoff with precipitation depth.

Useful records of monthly pool elevation and flood-release volumes were available from the BOR starting in January 1963, the year after the conservation pool was first filled. While these records were shorter than the precipitation and stream flow records, they were sufficiently long to investigate the effects of decade-long precipitation variations on pool elevation and floodrelease volumes. Again, comparison of flood releases with precipitation and reservoir inflow were facilitated by expressing flood releases as water depth over the watershed.

\section{Watershed Precipitation and Reservoir Inflow Variations}

Annual and 5-year weighted moving average (WMA) variations of watershed precipitation and reservoir inflow are shown in Figs. 2( $\mathrm{a}$ and $\mathrm{b}$ ). Weights of the moving average were determined from a sine function with maximum weight at the center of the moving average range and decreasing weights toward both ends of the range. The 5-year range was subjectively selected as a compromise between the increased ability of a longer WMA to filter out year-to-year variations and the need for recency of information for management decisions and actions. The selected 5-year WMA filters out year-to-year variations without losing above- or below-average departures lasting 5 years or longer called decadal variations.

A simple graphical approach was used to identify multiyear wet and dry precipitation periods in a time series (Fernandez and Garbrecht 1994). First, the cumulative sums of residuals of annual precipitation are calculated

$$
\mathrm{CSR}_{k}=\sum_{t=1}^{k} P_{t}-P_{a v} ; \quad k=1, \ldots, n
$$

where $\mathrm{CSR}=$ cumulative sum of residuals; $t=$ counter; $k=$ year counter limit of the current summation; $P=$ annual precipitation; $P_{a v}=$ average annual precipitation; and $n=$ time series length.

Then the cumulative sum of residuals is plotted versus time (Fig. 3). The steeply falling segments of the curve identify three distinct dry periods (1950-1956, 1963-1972, 1976-1980) and the 

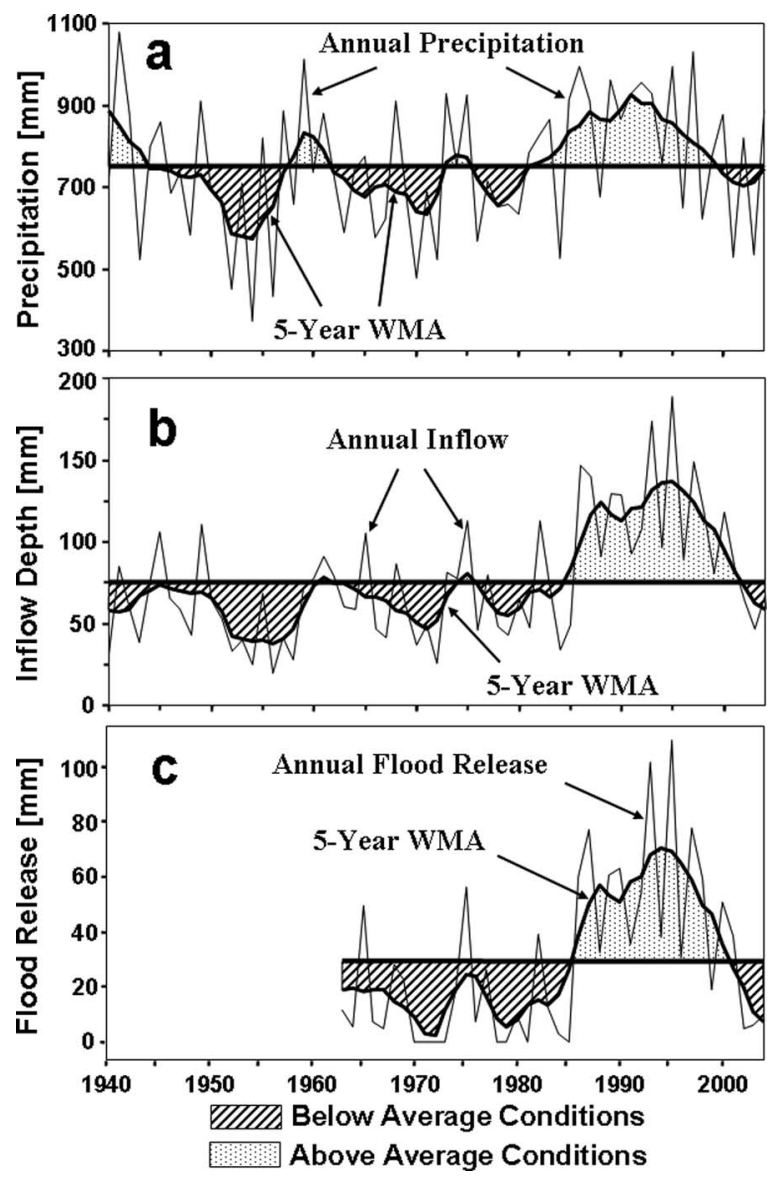

Fig. 2. Annual and 5-year weighted moving average of (a) watershed precipitation; (b) reservoir inflow; and (c) flood-release volume

steeply rising segment (1985-1997) identifies one wet period. A Wilcoxon-Mann-Whitney rank sum test showed that each wet and dry period was statistically different from the time series (onesided test and $p$ value of $0.02,0.04,0.06$ for the dry periods, respectively, and 0.003 for the wet period). In practical terms this means that the chance that each dry period is a true climatic phenomenon rather than a random sampling outcome is 98,96 , and $94 \%$, respectively, and greater than $99 \%$ for the wet period.

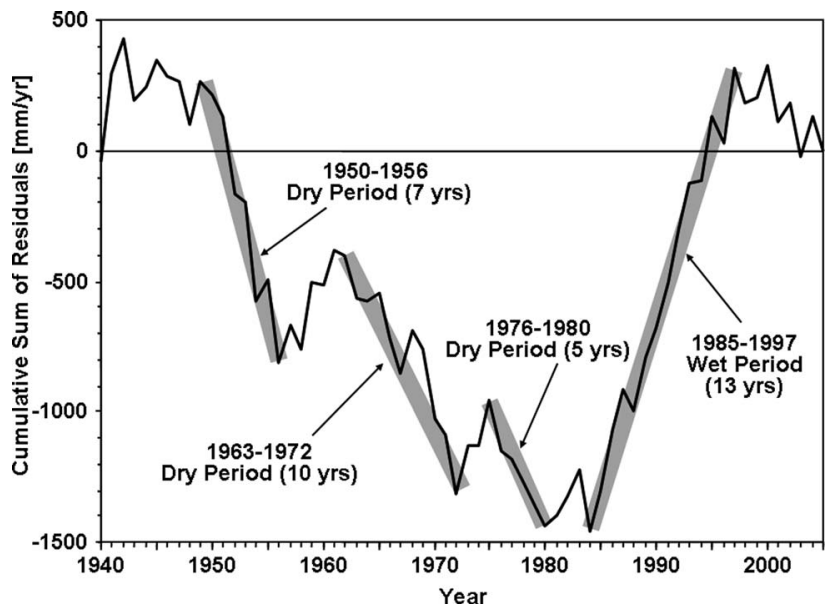

Fig. 3. Time series of cumulative sum of residuals and identification of dry and wet periods
Table 1. Summary Statistics of Mean Annual Watershed Precipitation $(P)$, Mean Annual Reservoir Inflow $(Q)$, and Mean Annual Flood-Release Volumes (FR) for the Defined Dry and Wet Periods

\begin{tabular}{|c|c|c|c|c|}
\hline Dry/wet period & $\begin{array}{l}\text { Number } \\
\text { of years }\end{array}$ & $\begin{array}{c}\text { Mean } \\
\text { annual } P \\
(\mathrm{~mm} / \text { year })\end{array}$ & $\begin{array}{c}\text { Mean } \\
\text { annual } Q \\
(\mathrm{~mm} / \text { year })\end{array}$ & $\begin{array}{c}\text { Mean } \\
\text { annual FR } \\
\text { (mm/year) }\end{array}$ \\
\hline \multicolumn{5}{|l|}{ All years } \\
\hline 1940-2004 & 65 & 752.0 & 75.5 & $38.0^{\mathrm{a}}$ \\
\hline \multicolumn{5}{|l|}{ Dry periods } \\
\hline $1951-1956$ & 6 & 576.0 & 39.9 & - \\
\hline 1964-1972 & 9 & 666.0 & 56.5 & 16.8 \\
\hline 1977-1980 & 4 & 665.0 & 58.7 & 11.8 \\
\hline Average & & 637.6 & 51.7 & 15.4 \\
\hline \multicolumn{5}{|l|}{ Wet period } \\
\hline 1986-1997 & 12 & 890.0 & 127.7 & 79.9 \\
\hline
\end{tabular}

The remaining years outside the dry and wet periods were classified as near neutral, meaning that precipitation values for these years did not reveal variations long enough, or of sufficient size, to be classified as a dry or wet period.

The identified wet and dry periods, with minor differences, are also present in the annual precipitation record of large sections of Oklahoma, pointing to coherent regional climatic structures (Garbrecht and Rossel 2002). They may be the result of global teleconnections that integrate the signal of various large-scale ocean-atmosphere circulations and dynamical chaotic processes into a single coherent climatic response. The search for teleconnections, forcing mechanisms, or other dynamical explanations for these wet/dry periods is outside the scope of this paper. The writers simply noted the existence of wet/dry periods and investigated their implications for water resources applications, such as the Fort Cobb Reservoir hydrology. The issue of predictability of wet/dry periods is addressed in the discussion section.

A qualitative review of the WMA of annual reservoir inflow also revealed three variations with below-average inflow (1950-1958, 1966-1972, 1978-1985) and one with aboveaverage inflow (1986-2001). Timing of these persistent low- and high-inflow variations corresponded closely to dry and wet precipitation variations, but was lagged due to the delayed response of the hydrologic watershed system (most likely related to groundwater levels and base flow) to changes in annual precipitation. A review of occurrence, timing, and duration of decadal precipitation and runoff variations suggested that the lag between the beginning of a dry or wet precipitation period, and corresponding runoff response, was on average 1 year. Therefore, in this investigation, the first year of any dry or wet period was considered to be a transition year for watershed response adjustment and excluded from the definition of dry and wet periods.

Dry and wet periods, corresponding mean annual watershed precipitation, and reservoir inflow are given in Table 1. On average, mean annual precipitation was 638 and $890 \mathrm{~mm} /$ year for dry and wet periods, respectively, with a difference of $250 \mathrm{~mm} /$ year or 33\% of the 1940-2004 mean. Probability of exceedance curves of annual precipitation [Fig. 4(a)] displayed a sizable shift in precipitation between wet and dry periods. There was an $82 \%$ probability of exceeding the 1940-2004 mean of $752 \mathrm{~mm}$ /year during a wet period, but only a $16 \%$ probability during a dry period.

With regard to reservoir inflow, mean annual inflow was 51.7 and $127.7 \mathrm{~mm} /$ year during dry and wet periods, respectively, with a difference of $76 \mathrm{~mm} /$ year, or $100 \%$ of the 1940-2004 mean. Thus, only about 8 and $14 \%$ of precipitation contributed to 

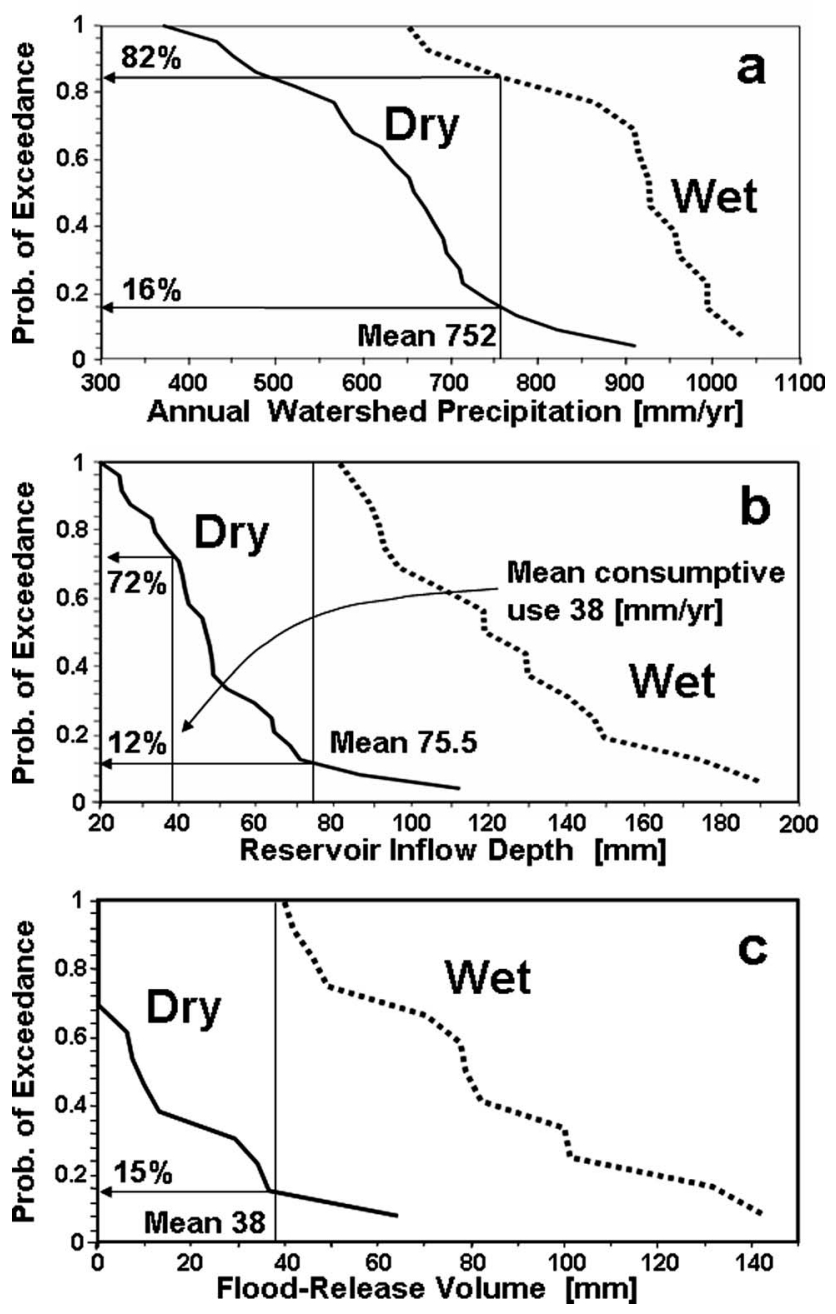

Fig. 4. Probability of exceedance curves of (a) watershed precipitation $(P)$; (b) reservoir inflow $(Q)$; and (c) flood releases (FR) for wet and dry periods

reservoir inflow for dry and wet periods, respectively. Such small precipitation contributions to reservoir inflow from surface flow may give the impression that decadal precipitation variations have little impact on reservoir inflow. However, nonlinear precipitation-runoff production mechanisms are sensitive to precipitation variations, as revealed by the $100 \%$ change in mean annual reservoir inflows resulting from the $33 \%$ change in mean annual precipitation.

This sensitivity of reservoir inflow to annual precipitation was attributed to two mutually amplifying precipitation-runoff factors: first, an increase in precipitation per storm during wet periods led to higher runoff, and second, an increase in the number of storms during wet periods (Garbrecht et al. 2002) led to generally higher soil saturation conditions and lower infiltration potential, which in turn enhanced runoff. On the other hand, during dry periods, lower runoff due to lower precipitation amounts was further reduced by generally lower soil saturation conditions and higher infiltration potential.

As a result of this precipitation-runoff sensitivity, the probability of exceedance curves for reservoir inflow [Fig. 4(b)] shows a greater difference between dry and wet periods than for precipitation, with a $100 \%$ probability of exceeding the 1940-2004 mean of $75.5 \mathrm{~mm}$ /year during a wet period compared to a $12 \%$ prob-
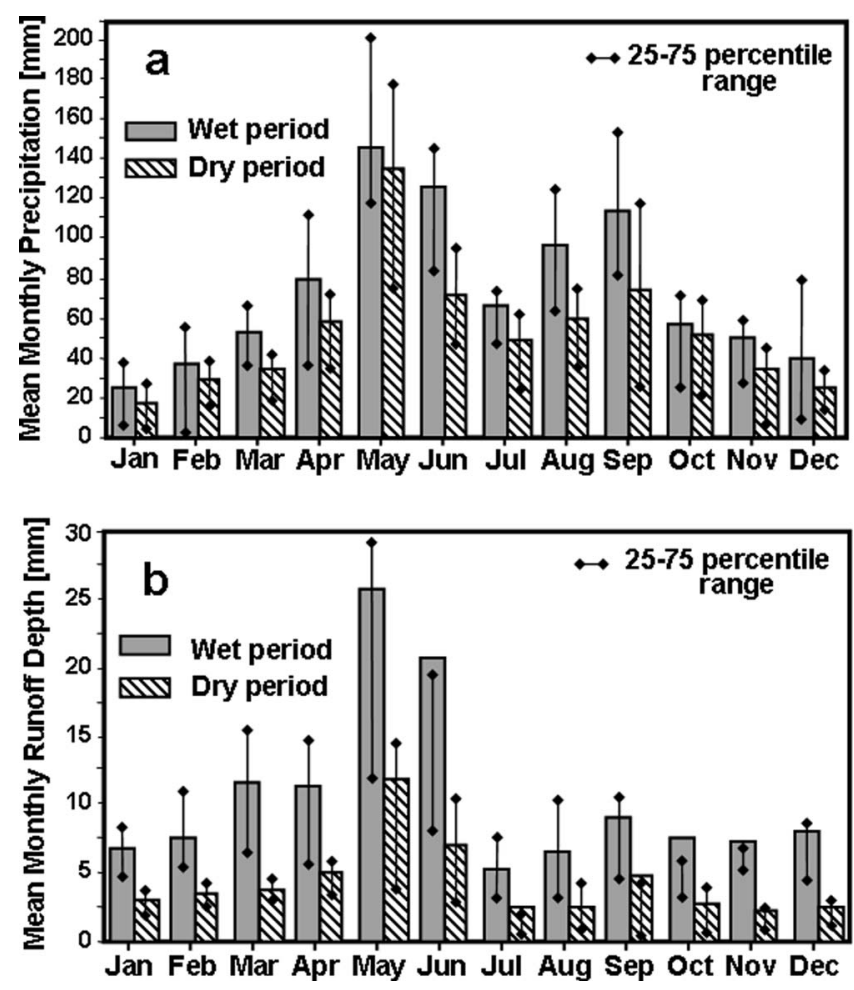

Fig. 5. Annual distribution of mean monthly precipitation and reservoir inflows for dry and wet periods (dry periods: 1951-1956, 1964-1972, 1977-1980; wet period: 1986-1997)

ability during a dry period. The probability curves also indicate that during a wet period, reservoir inflow always exceeded the consumptive water use of $38 \mathrm{~mm} /$ year for municipal and industrial withdrawals, evaporation, and seepage losses, whereas during a dry period there was a $28 \%$ chance that consumptive use exceeded reservoir inflows.

Monthly distributions of precipitation and reservoir inflow for dry and wet periods are shown in Fig. 4. Precipitation distributions show a bimodal pattern with the first mode in May and June and the second in August and September [Fig. 5(a)]. Differences in mean monthly precipitation between dry and wet periods are modest for most months. Only June, August, and September display a sizeable difference with mean precipitation of dry periods situated outside of the 25-75 percentile range of the wet period. On the other hand, reservoir inflow distributions have only a single mode in May and June [Fig. 5(b)]. The runoff response to the precipitation mode of August and September was likely dampened by higher evapotranspiration (ET) activity during hot and drier summer months. More revealing was the sizable difference in reservoir inflows between dry and wet periods for all months, with December through June showing the greatest differences.

\section{Watershed Precipitation and Reservoir Flood-Release Variations}

Flood releases are the result of excessive reservoir inflows. As such the similarity in WMA variations of precipitation, reservoir inflow, and flood releases (Fig. 2) does not come as a surprise. Flood releases were 15.4 and $79.9 \mathrm{~mm}$ /year for dry and wet periods, respectively (Table 1), with a difference of $64.5 \mathrm{~mm} /$ year or $170 \%$ of the 1963-2004 mean. Thus, the 33\% difference in 


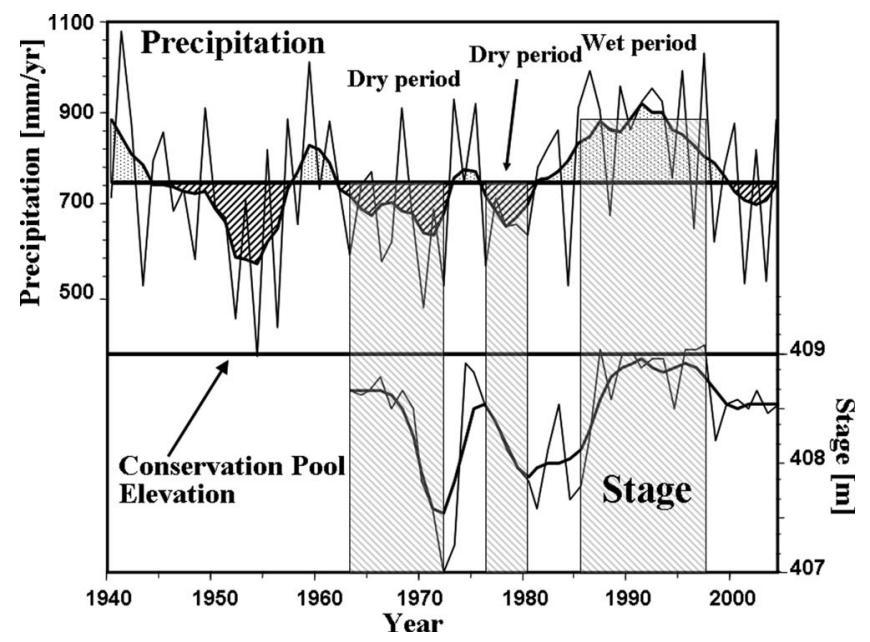

Fig. 6. 1963-2004 time series of annual and WMA minimum pool elevation (dry periods: 1964-1972, 1977-1980; wet periods: 1986-1997)

average precipitation between wet and dry periods resulted in a corresponding $170 \%$ difference in flood releases. The sensitivity of flood releases to decadal precipitation variations is also seen in the probability of exceedance curves in Fig. 4(c). The probability of exceeding the 1963-2004 mean annual flood release was $100 \%$ during the wet period compared to $15 \%$ during dry periods, and there was a $28 \%$ probability of having no flood releases at all during dry periods, while all years had flood releases during the wet period. Thus, during wet periods, one can expect to see increased flood control operations.

On a monthly basis, mean flood releases display a pattern similar to that of reservoir inflows (Fig. 5), with May and June having the largest mean flood release amount. A review of individual monthly flood release values showed that a large monthly value can occur in any month of the year, irrespective of dry or wet period, though the frequency of large values was higher during the wet period.

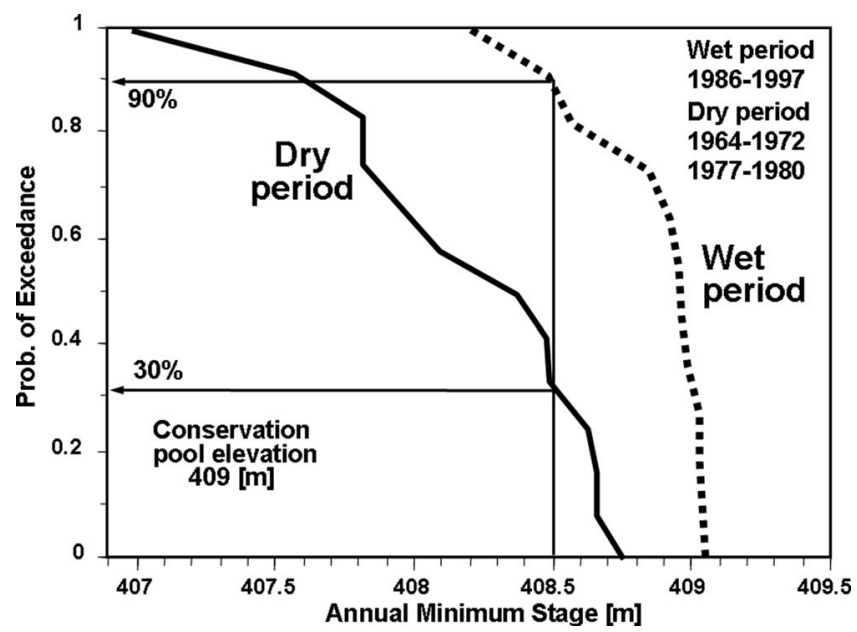

Fig. 7. Probability of exceedance curves of annual minimum pool elevation for dry and wet periods

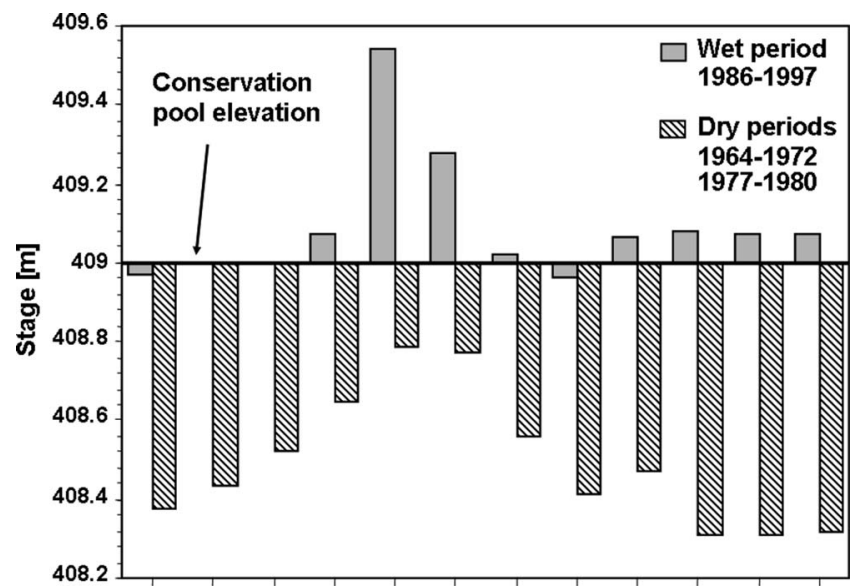

Jan Feb Mar Apr May Jun Jul Aug Sep Oct Nov Dec

Fig. 8. Annual distribution of mean monthly reservoir pool elevations for dry and wet periods

\section{Watershed Precipitation and Reservoir Pool-Elevation Variations}

Pool elevation reflects the interplay between reservoir inflows, consumptive water use, and flood releases. For the Fort Cobb reservoir, flood pool elevations above $409 \mathrm{~m}$ mean sea level (MSL) are regulated by gate-operated flood releases. Under these regulated conditions, pool elevation is not suitable for assessing impacts of decade-long precipitation variations. However, conservation pool elevations at and below $409 \mathrm{~m}$ MSL are unregulated and can serve as a suitable indicator of cumulative effects of decadal precipitation variations on lake accessibility, recreational opportunities, and related commercial activity.

Conservation pool elevations decline when consumptive water use exceeds reservoir inflows, and the reverse is true when reservoir inflow exceeds consumptive use. A time-series plot of annual and WMA minimum pool elevations (Fig. 6) displays decreasing pool elevations during the 1964-1972 and 1977-1980 dry periods with lowest elevation at the end of either dry period, a reflection of the cumulative effects of dry periods. During the 1986-1997 wet period, pool elevation rises to the top of the conservation pool, which then is maintained by flood releases. The probability of exceedance curves in Fig. 7 shows the frequency with which annual minimum pool elevations below 409 m MSL occur during dry and wet periods. During the wet period, annual minimum pool elevation never dropped below $408 \mathrm{~m} \mathrm{MSL}$, and $90 \%$ of the time it was within half a meter of the top of the conservation pool (CP). During dry periods, annual minimum pool elevation was always above $407 \mathrm{~m}$ MSL ( $2 \mathrm{~m}$ below top of $\mathrm{CP}$ ), and $70 \%$ of the time it was more than half a meter below top of CP.

Annual distribution of mean monthly pool elevation is displayed in Fig. 8. During wet periods, mean pool elevation in May and June is above $409 \mathrm{~m} \mathrm{MSL}$, an indication that flood releases often occur in these months, whereas it is at or near the top of the conservation pool for all other months of the year. Thus, during wet periods one can expect the conservation pool to be, on average, full every calendar month. On the other hand, during dry periods, mean pool elevation is below $409 \mathrm{~m}$ MSL for all months of the year, with October through January having the lowest elevation. These are also the months with lowest reservoir inflows. 


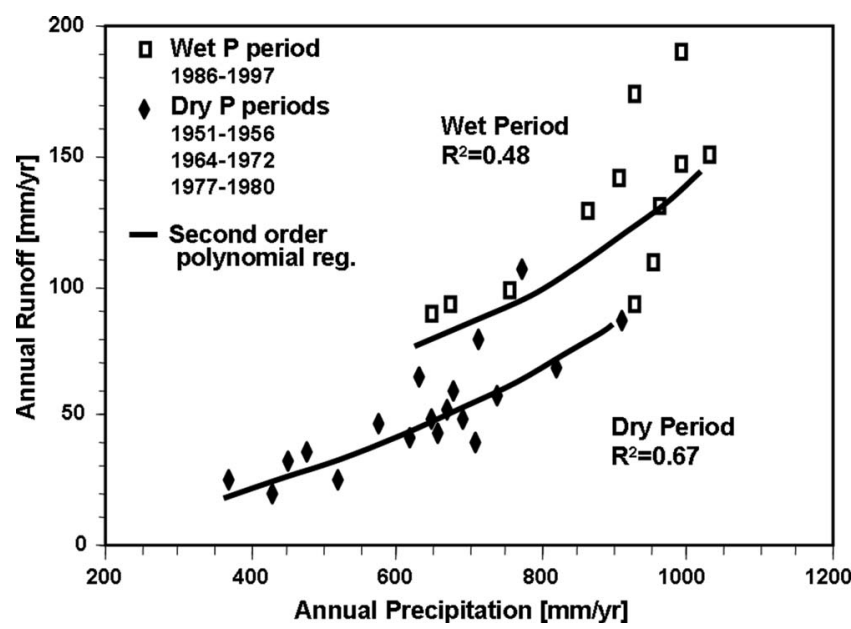

Fig. 9. Relationship between annual precipitation and reservoir inflow runoff for dry and wet periods

\section{Discussion}

The observed difference in precipitation between dry and wet periods (33\% of mean) and resulting change in reservoir inflows ( $100 \%$ of mean) will likely also be reflected in the sediment loading of the reservoir. Indeed, one can reason that the large change in reservoir inflows between dry and wet periods is the result of related changes in upland runoff, which affect soil erosion and sediment transport. Specifically, a power-function relationship exists between suspended sediment and runoff (Graf 1971; Vanoni 1975), which suggests that even larger differences in soil erosion and transport between wet and dry periods are possible than was observed for runoff. Similar inferences likely apply for the movement of agrichemicals, since many such substances are adsorbed to soil particles and transported with sediment. Thus, one can anticipate that watershed runoff and many runoff-related processes in the Fort Cobb watershed will respond sensitively to decadal precipitation variations, and careful consideration may be warranted in the interpretation of hydrologic records and sediment yields estimation that span a limited number of years.

Decade-long precipitation variations may also affect calibration and validation of hydrologic and environmental simulation models. Model calibration will inherently reflect climate, runoff, soil erosion, and transport relationships that prevailed during the calibration time period. A plot of annual reservoir inflow versus precipitation for dry and wet periods (Fig. 9) demonstrates this point for the Fort Cobb Reservoir watershed. The annual precipitation-inflow relationship for wet periods is vertically shifted upward from the relationship representing dry periods. The size of the vertical shift is about $40 \mathrm{~mm}$, or about $50 \%$ of mean inflow. Given the large differences in reservoir inflow due to decade-long precipitation variations, it remains to be seen if a model calibrated under either a wet or dry period is valid for application under precipitation variations that are different than those used in the model calibration. Such a validation is recommended when the model is either applied with long-term precipitation data that include decade-long variations, or with precipitation data that are different in character from those used in the model calibration.

Commercial enterprises and recreational opportunities on the reservoir may also be affected by varying pool elevations associ- ated with decadal precipitation variations. During wet periods, the reservoir will likely experience more frequent but short-lived flooding of shoreline campgrounds, parks, and access roads. During dry periods, sustained low water elevations are the primary concern. The lowest pool elevation of $407 \mathrm{~m}$ MSL was observed in November 1972 at the end of the 1964-1972 dry period and represented a $2 \mathrm{~m}$ elevation drop from the top of the conservation pool. A $2 \mathrm{~m}$ drop in pool elevation is small compared to the elevation range of the conservation pool $(13 \mathrm{~m})$ and is unlikely to affect water supply functions. However, low water levels may restrict use of boat access ramps, limit marina operations, and curb shoreline activities such as camping, swimming, and fishing opportunities. In the Fort Cobb reservoir, water levels lower than $408 \mathrm{~m}$ MSL occurred about $40 \%$ of the time during dry periods. While lower reservoir water levels during dry periods are not affecting water supply operations under current consumptive water uses, they can restrict commercial and recreational activities.

Decadal precipitation variations seem to hold few potential benefits for stream ecosystem downstream of the Fort Cobb reservoir. While differences in flood release amounts between wet and dry periods was substantial (170\% of mean) and led to increased downstream flow, characteristics of flood releases are not well suited to support a stable riparian ecosystem. Under normal operating conditions, the gate-controlled flood release rates are at or slightly below the downstream channel capacity to avoid flooding (about $28 \mathrm{~cm}$; R. Bell, USACE, Tulsa District, personal communication, 2004), and releases last only long enough to empty the flood control pool.

Outside flood release periods, stream flow immediately downstream of the reservoir consists only of minor seepage flows from the reservoir. At first, the increased downstream flow due to flood releases during wet periods could be construed as beneficial to the stream ecosystem. Yet the sporadic nature, short duration, high rates, and timing of flood releases are not believed to hold significant potential to enhance stream habitat and riparian vegetation downstream of the reservoir. Benefits for riparian vegetation and stream habitat could be increased by minimum reservoir releases during dry periods and critical growth season, but this would come at the expense of lower pool elevations, which in turn may affect recreational and commercial activities on the reservoir.

While impacts of recent decadal precipitation variations on the hydrology of Fort Cobb Reservoir are readily recognized, prediction of occurrence, duration, and intensity of future variations would be highly desirable for planning and management of reservoir operations. Such predictions would have to be based on the state of large-scale ocean-atmosphere circulation patterns across the world's oceans. In turn, the state of ocean-atmosphere circulation patterns would be linked via teleconnections to the climate in central Oklahoma. Unfortunately, the current state of knowledge of large-scale ocean-atmosphere circulation patterns does not include any useful predictive skill at the interannual-todecadal time scale (NRC 1998), let alone establishing dependable predictive linkages to decadal precipitation variations at far away locations (Watkins and O'Connell 2006). Part of the problem is a general mismatch between the focus of teleconnection/forecast studies, which deal with identification and prediction of monthly and seasonal anomalies (Zebiac 2003), and the interannual-todecadal time scales under study in this paper. Thus, predicting decadal precipitation variations does not hold much promise at this time and was not pursued here. 


\section{Conclusions}

The impact of decadal precipitation variations on reservoir hydrology was investigated for the Fort Cobb Reservoir in central Oklahoma. Three dry periods and one wet period were identified in the 1940-2004 precipitation record. The difference in mean annual precipitation between dry and wet periods was $33 \%$ of the mean and led to a corresponding $100 \%$ change in mean reservoir inflow, a $170 \%$ change in mean annual flood releases from the reservoir, and a maximum pool elevation drop of $2 \mathrm{~m}$ from the top of the conservation pool. Thus, watershed runoff, reservoir inflow, and flood releases were highly sensitive to decadal precipitation variations.

Yet, the only reservoir operation that appeared to be impacted by decadal precipitation variations was the frequency of flood release activities. High reservoir inflows during wet periods led to an increase in flood releases. Increased frequency of downstream stream flow was not believed to appreciably enhance stream habitat and riparian vegetation, due to the sporadic and intermittent nature of flood releases. The lowering of the conservation pool elevations during dry periods was moderate and did not impact reservoir operations or the water supply function of the reservoir, but can impact commercial and recreational activities associated with access to the shoreline, such as utilization of boat ramps, access to marinas, and use of beaches and waterfront campgrounds.

It was further reasoned that reservoir sediment loading would be as sensitive to decadal precipitation variations as reservoir inflows, perhaps even more sensitive due to the exponential relationship between stream flow and sediment transport capacity. However, reservoir sedimentation cannot be controlled by reservoir operations and must be addressed by soil conservation measures and stream stabilization in the watershed itself. With regard to hydrologic and environmental modeling, it was argued that decadal precipitation variations should be considered in the selection of consistent data sets for model calibration, verification, and subsequent application. Overall, this case study demonstrated the important role that decadal precipitation variations may have on watershed hydrology and suggested that decadal precipitation variations deserve careful consideration in hydrologic and water quality investigations in central Oklahoma.

\section{References}

Crawford, K. C., et al. (1992). "The Oklahoma Mesonetwork-A 21st century project." Preprint Vol., 8th Int. Conf. on Interactive Information and Processing Systems for Meteorology, Oceanography and Hydrology, American Meteorological Society, Boston, 27-33.

Croley, T. E., II. (1995). "Chapter 9: Laurentian Great Lakes: Dynamics, climate, and response to change." The role of water and the hydrological cycle in global change, H. R. Oliver and S. A. Oliver, eds., Springer, Berlin, 253-296.

Dettinger, M. D., Cayan, D. R., Diaz, H. F., and Meko, D. M. (1998). "North-south precipitation patterns in western North America on interannual-to-decadal timescales." J. Clim., 11(12), 3095-3111.

Elliott, R. L., Brock, F. V., Stone, M. L., and Harp, S. L. (1994). "Configuration decisions for an automated weather station network." Appl. Eng. Agric., 10(1), 45-51.

Fernandez, G. P., and Garbrecht, J. D. (1994). "Effect of trends and longterm fluctuations of rainfall on watershed runoff." Trans. ASAE,
37(6), 1841-1844.

Garbrecht, J., Van Liew, M., and Brown, G. O. (2004). “Trends in precipitation, streamflow, and evapotranspiration in the Great Plains of the United States." J. Hydrol. Eng., 9(5), 360-367.

Garbrecht, J. D., and Rossel, F. E. (2002). "Decade-scale precipitation increase in Great Plains at end of 20th century." J. Hydrol. Eng., 7(1), 64-75.

Garbrecht, J. D., Schneider, J. M., and Zhang, X. C. J. (2002). "How are decade-scale precipitation variations reflected in the daily precipitation record?" Proc., 13th Symp. on Global Change and Climate Variations, American Meteorological Society, Boston, 45-47.

Graf, W. H. (1971). Hydraulics of sediment transport, McGraw-Hill, New York.

Gray, S. T., Jackson, S. T., and Betancourt, J. L. (2004). “Tree-ring based reconstruction of interannual to decadal scale precipitation variability for northeastern Utah since 1226 A.D." J. Am. Water Resour. Assoc., 40(4), 947-960.

Hu, Q., Woodruff, C. M., and Mudrick, S. E. (1998). "Interdecadal variations of annual precipitation in the central United States." Bull. Am. Meteorol. Soc., 79(2), 221-229.

Lall, U., and Mann, M. (1995). "The Great Salt Lake: A barometer of low-frequency climate variability." Water Resour. Res., 31(10), 2503-2516.

Mantua, N. J., Hare, S. R., Zhang, Y., Wallace, J. M., and Francis, R. C. (1997). "A Pacific interdecadal climate oscillation with impacts on salmon production.” Bull. Am. Meteorol. Soc., 78(6), 1070-1079.

Mausbach, M. J., and Dedrick, A. R. (2004). "The length we go: Measuring environmental benefits of conservation practices." J. Soil Water Conservat., 59(5), 97-103.

National Research Council (NRC). (1998). "Decade-to-century-scale climate variability and change: A science strategy." Panel on Climate Variability on Decade-to-Century Time Scales, Board on Atmospheric Sciences and Climate, Commission on Geosciences, Environment, and Resources, Washington, D.C.

Oklahoma Climatological Survey (OCS). (2005). Oklahoma Climate Data 1996-2006, Univ. of Oklahoma, Norman, Okla., 〈http://climate. ocs.ou.edu/> (December 2005).

Storm, D. E., White, M. J., and Stoodley, P. R. (2006). "Fort Cobb Basin-Modeling and land cover classification." Final Rep. for the Oklahoma Dept. of Environmental Quality, Dept. of Biosystems and Agricultural Engineering, Oklahoma State Univ., Stillwater, Okla.

United States Geological Survey (USGS). (2005). National Water Information System (NWIS), USGS Surface Water Data for the Nation, $\langle$ http://waterdata.usgs.gov/usa/nwis/sw $\rangle$ (December 2005).

Vanoni, V. A., ed. (1975). Sedimentation engineering, ASCE, New York.

Watkins, , D. W., Jr., and O'Connell, S. M. (2006). “Teleconnections and disconnections in central Texas: A guide for water managers." Climate variations, climate change, and water resources engineering, J. D. Garbrecht and T. C. Piechota, eds., ASCE, Reston, Va.

Webb, R. H., McCabe, G. J., Hereford, R., and Wilkowske, C. (2004). "Climate fluctuations, drought, and flow in the Colorado River." USGS fact sheet 3062-04, U.S. Geological Survey, U.S. Dept. of the Interior, 〈http://water.usgs.gov/pubs/fs/2004/3062〉 (December 2005).

Woodhouse, C. A., and Overpeck, J. T. (1998). "2000 years of drought variability in the central United States." Bull. Am. Meteorol. Soc., 79(12), 2693-2714.

Worster, D. E. (1982). Dust bowl: The Southern Plains in the 1930s, Oxford Univ. Press, New York.

Yue, P., and Derichsweiler, M. (2005). "TMDL development for Fort Cobb Creek watershed and Fort Cobb Lake." Proc., Oklahoma Water Conf. 2005, Environmental Institute and Biosystems and Agricultural Engineering Dept., Oklahoma State Univ., Stillwater, Okla.

Zebiac, S. E. (2003). "Research potential for improvement in climate prediction." Bull. Am. Meteorol. Soc., 84(12), 1692-1696. 